\title{
Spawanie stali - narażenie na cząstki zawarte w dymach spawalniczych
}

\author{
Welding steel - exposure to particles presented \\ in the welding fume
}

\section{Streszczenie}

W artykule przedstawiono wyniki badania stężeń i rozkładów wymiarowych cząstek emitowanych do środowiska pracy podczas spawania stali elektrodami ER-150/F 6013. Badania wykonane metodą filtracyjno-wagową (próbniki typu PCIS) oraz metodami zliczania (AERO-TRAK, GRIMM, DUST-TRAK) wykazały, że podczas całego dnia pracy spawacz może być narażony na zmienne ilości cząstek z reguły o wymiarach poniżej $10 \mu \mathrm{m}$, przy czym dymy spawalnicze zwykle zawierają znaczne ilości cząstek ultradrobnych i drobnych o wymiarach poniżej $1 \mu \mathrm{m}$.

\section{Wstęp}

Spawanie jest procesem wysokotemperaturowym występującym zarówno w środowisku pracy, jak i życia. W wyniku spawania do otaczającego powietrza są emitowane szkodliwe zanieczyszczenia w postaci gazów oraz cząstek stałych, $z$ reguły o wymiarach poniżej $10 \mu \mathrm{m}$, przy czym dymy spawalnicze zwykle zawierają znaczne ilości cząstek ultradrobnych i drobnych o wymiarach poniżej $1 \mu \mathrm{m}$.

Zasady i metody pomiarowe aktualnie wykorzystywane do oceny narażenia zawodowego na zanieczyszczenia emitowane podczas spawania są przedstawione $w$ normach $i$ przepisach prawa $[1 \div 6]$ oraz omówione w piśmiennictwie [7]. W przypadku oceny narażenia na cząstki pyłów zalecane jest przede wszystkim wykorzystywanie metody filtracyjno-wagowej, polegającej na pobieraniu próbek pyłów na filtry

Dr inż. Elżbieta Jankowska - Centralny Instytut Ochrony Pracy, Państwowy Instytut Badawczy. pomiarowe i określaniu stężeń badanych frakcji (np. pyłu całkowitego, pyłu respirabilnego itp.) metodą wagową. Jej stosowanie nie odzwierciedla jednak rzeczywistego narażenia pracowników na cząstki emitowane podczas spawania, gdyż nie umożliwia określenia ich tak istotnych parametrów - szczególnie w odniesieniu do cząstek ultradrobnych i drobnych - jak rozkłady wymiarowe oraz stężenia liczbowe i powierzchniowe [8, 9]. Wiedza na ten temat jest szczególnie ważna $z$ uwagi na fakt, że szkodliwe działanie na organizm człowieka cząstek ultradrobnych i drobnych może mieć inny charakter niż działanie cząstek o większych wymiarach. Przede wszystkim dotyczy to cząstek ultradrobnych (poniżej 100 nm), które są uważane za bardzo niebezpieczne dla zdrowia człowieka, gdyż mogą przenikać do krwi i być powodem dotychczas jeszcze nierozpoznanych chorób zawodowych.

W artykule [9] przedstawiono wyniki badania parametrów cząstek emitowanych podczas spawania stali kwasoodpornej elektrodami OK 61.30/308L-17. Celem badań przedstawionych w artykule było określenie stężeń i rozkładów wymiarowych cząstek zawieszonych w powietrzu w spawalni, emitowanych podczas spawania stali elektrodami ER-150/F 6013. 


\section{Warunki i metodyka badań}

Badania wykonano w pomieszczeniu spawalni o wymiarach: długość 4,6 m, szerokość 4,4 m i wysokość 3,2 m. Pomiary przeprowadzono metodą filtracyjno-wagową i metodami zliczania w strefie oddychania spawacza:

- przed rozpoczęciem pracy spawacza (nocą i rano),

- podczas całego dnia pracy spawacza, w tym podCzas spawania stali elektrodami ER-150/F 6013.

Pomiary wykonywano przy zamkniętych oknach i drzwiach spawalni (drzwi prowadzące na korytarz były otwierane tylko na bardzo krótkie okresy, wynikające z konieczności ruchu osób uczestniczących w badaniach), przy czym powietrze z zewnątrz mogło przedostawać się przez nieszczelności występujące w okolicach okien i drzwi. Na rysunku 1 przedstawiono ogólny widok procesu spawania wykonywanego podczas badań oraz pokazano lokalizację punktów pomiarowych do pobierania próbek do oznaczania stężeń metodą filtracyjno-wagową i metodami zliczania. Szczegółowy program wykonywania badań i prowadzenia prac spawalniczych przedstawiono w tablicy I.

Badania stężeń i rozkładów wymiarowych cząstek przeprowadzono z użyciem:

- próbników PCIS z pompkami SKC 100-3000 (stężenia frakcji $\mathrm{PM}_{0,25}, \mathrm{PM}_{0,5}, \mathrm{PM}_{1}, \mathrm{PM}_{2,5}$ i $\mathrm{PM}_{10}$ cząstek),

- miernika AERO-TRAK 9000, TSI (stężenia powierzchniowe cząstek o wymiarach $0,01 \div 1 \mu \mathrm{m}$ frakcji A - Alveolar),
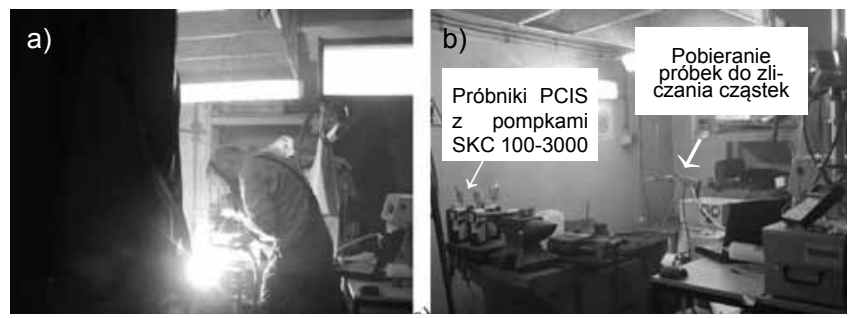

Rys. 1. Spawalnia: a) ogólny widok procesu spawania wykonywanego podczas badań, b) lokalizacja punktów pomiarowych do pobierania próbek do oznaczania stężeń cząstek metodą filtracyjno-wagową i metodami zliczania

Fig. 1. Welding shop: a) general view of welding process during measurements, b) location of sampling points for taking samples to determined particles concentrations with gravimetric and counting methods

Tablica I. Program wykonywania badań i prowadzenia prac spawalniczych

Table I. Program of measurements and conducting of welding works

\begin{tabular}{|l|l|}
\hline \multicolumn{1}{|c|}{ Miejsce badań } & Prowadzone prace spawalnicze \\
\hline $\begin{array}{l}\text { „Tło" w spawalni od godz. } \\
\text { 00:00 do godz. 08:14 }\end{array}$ & Nie prowadzono \\
\hline & $\begin{array}{l}\text { Spawanie stali elektrodami } \\
\text { ER-150/F 6013: }\end{array}$ \\
Spawalnia - podczas pro- & $10: 04$ - spawanie 2 elektrodami \\
wadzenia prac spawalni- & $10: 40$ - spawanie 2 elektrodami \\
czych & $11: 07$ - spawanie 1 elektrodą \\
& $12: 17$ - spawanie 2 elektrodami \\
& $13: 10$ - spawanie 2 elektrodami \\
\hline $\begin{array}{l}\text { Spawalnia - po zakoń- } \\
\text { czeniu spawania od godz. }\end{array}$ & Nie prowadzono \\
13:12 do godz. 15:23 & \\
\hline
\end{tabular}

- licznika optycznego GRIMM model 1,108 (stężenia liczbowe oraz rozkłady wymiarowe cząstek z zakresów: $0,4 \div 0,5 \mu \mathrm{m}, 0,5 \div 1 \mu \mathrm{m}, 1 \div 3 \mu \mathrm{m}$ i $3 \div 10 \mu \mathrm{m}$ ),

- miernika DUST-TRAK, TSI model 8520 (stężenia masowe cząstek o wymiarach $0,1 \div 10 \mu \mathrm{m}$ ).

\section{Wyniki badań}

Wyniki badania stężeń masowych frakcji $\mathrm{PM}_{0,25}$, $\mathrm{PM}_{0.5}, \mathrm{PM}_{1}, \mathrm{PM}_{2.5}$ i $\mathrm{PM}_{10}$ cząstek z zastosowaniem próbników PCIS z pompkami SKC 100 $\div 3000$ zestawiono w tablicy II, natomiast wyniki badania parametrów cząstek metodami zliczania przedstawiono odpowiednio:

- na rysunkach 2 i 3 - stężenia powierzchniowe cząstek $0,01 \div 1 \mu \mathrm{m}$ (AERO-TRAK),

- na rysunkach 4 i 5 - stężenia liczbowe czastek z zakresów $0,4 \div 0,5,0,5 \div 1,1 \div 3$ i 3 $\div 10 \mu \mathrm{m}$ (GRIMM),

- na rysunkach 6 i 7 - stężenia masowe cząstek $0,1 \div 10 \mu \mathrm{m}$ (DUST-TRAK).

Podczas wykonywania badań narażenia spawacza na cząstki zawarte $w$ dymach spawalniczych temperatura powietrza w spawalni wynosiła $25 \div 28^{\circ} \mathrm{C}$, natomiast wilgotność względna $54 \div 57 \%$.

Z danych przedstawionych w tablicy II wynika, że podczas spawania stali elektrodami ER-150/F 6013 (zgodnie z programem przedstawionym $\mathrm{w}$ tablicy I) średnie stężenia mierzonych frakcji wymiarowych cząstek $\left(\mathrm{PM}_{0,25}, \mathrm{PM}_{0,5}, \mathrm{PM}_{1}, \mathrm{PM}_{2,5}\right.$ i $\left.\mathrm{PM}_{10}\right)$ zawierały się w przedziale $4,39 \div 6,87 \mathrm{mg} / \mathrm{m}^{3}$, a średnie udziały frakcji drobniejszych $\left(\mathrm{PM}_{0.25}, \mathrm{PM}_{0,5}, \mathrm{PM}_{1}, \mathrm{PM}_{2,5}\right)$ we frakcji PM10 wynosiły $64 \div 78 \%$. Podczas procesu spawania były w większości emitowane cząstki ultradrobne i drobne, o wymiarach poniżej $1 \mu \mathrm{m}(70 \%)$.

Dane przedstawione na rysunkach 2, 4 i 6 wskazują na to, że w nocy i rano przed rozpoczęciem pracy spawacza:

- stężenia powierzchniowe cząstek o wymiarach $0,01 \div 1 \mu \mathrm{m}$ (pomiary AERO-TRAK) utrzymywały sięw spawalni w zakresie $36 \div 55 \mu \mathrm{m}^{2} / \mathrm{cm}^{3}$, przy czym najwyższe stężenia powierzchniowe występowały w nocy - prawdopodobnie jako efekt spawania w dniu poprzednim - i rano, kiedy były prowadzone prace przygotowawcze przed badaniami - prawdopodobnie w wyniku wpływu ruchu powietrza i obecności osób (rys. 2),

Tablica II. Średnie stężenia masowe frakcji $\mathrm{PM}_{025}, \mathrm{PM}_{0.5}, \mathrm{PM}_{1}, \mathrm{PM}_{25}$ i $\mathrm{PM}_{10}$ cząstek zawartych $\mathrm{w}$ dymach spawalniczych określone metodą filtracyjno-wagową z użyciem próbników PCIS

Table II. Average mass concentrations of fractions $\mathrm{PM}_{0.25}, \mathrm{PM}_{0.5}$, $\mathrm{PM}_{1}, \mathrm{PM}_{25}$ and $\mathrm{PM}_{10}$ particles in the welding fumes determined with gravimetric method with used of PCIS samplers

\begin{tabular}{|c|c|c|}
\hline $\begin{array}{c}\text { Frakcje } \\
\text { pyłu }\end{array}$ & $\begin{array}{c}\text { Średnie stężenie } \\
\text { pyłu, } \mathrm{mg} / \mathrm{m}^{3}\end{array}$ & $\begin{array}{c}\text { Średni udział w odniesieniu } \\
\text { do frakcji } \mathrm{PM}_{10} \%\end{array}$ \\
\hline $\mathrm{PM}_{0.25}$ & 4,39 & 64 \\
\hline $\mathrm{PM}_{0.5}$ & 4,49 & 65 \\
\hline $\mathrm{PM}_{1}$ & 4,81 & 70 \\
\hline $\mathrm{PM}_{2.5}$ & 5,34 & 78 \\
\hline $\mathrm{PM}_{10}$ & 6,87 & - \\
\hline
\end{tabular}




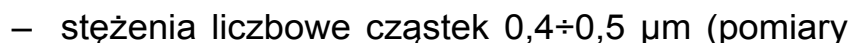
GRIMM) zawierały się w zakresie $1,3 \div 2,3 e^{4}$ cząstek $/ \mathrm{dm}^{3}$, natomiast cząstek $0,5 \div 1 \mu \mathrm{m}$ w zakresie $0,4 \div 1,0 e^{4}$ cząstek $/ \mathrm{dm}^{3}$, i dla obydwu ww. zakresów wymiarowych jest widoczny większy wpływ prowadzenia prac spawalniczych wykonywanych

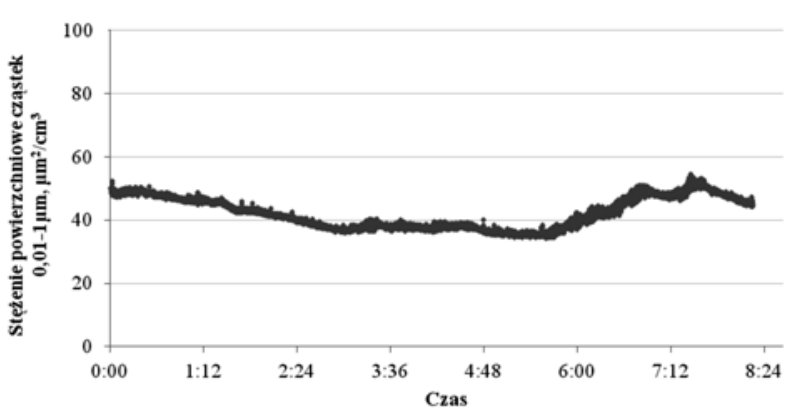

Rys. 2. Stężenie powierzchniowe cząstek z zakresu $0,01 \div 1 \mu \mathrm{m}$ w powietrzu w spawalni („,to” w spawalni) przed rozpoczęciem spawania (pomiary AERO-TRAK)

Fig. 2. Surface concentration of particles from the range $0,01 \div 1 \mu \mathrm{m}$ in the air in the welding shop ("background" in the welding shop) before welding (measurements with AERO-TRAK)

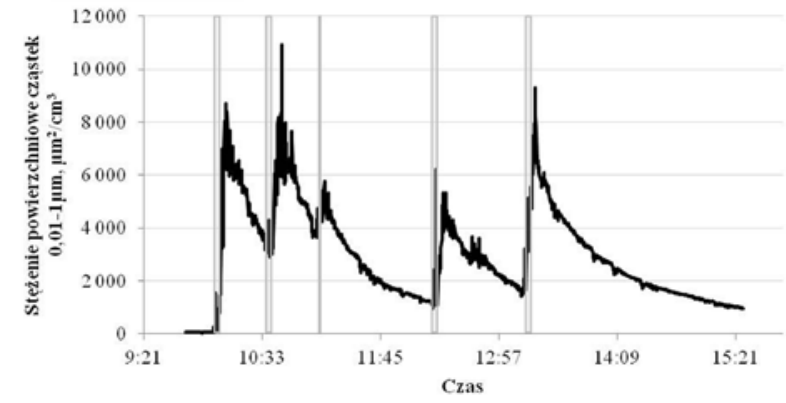

Rys. 3. Stężenie powierzchniowe cząstek z zakresu $0,01 \div 1 \mu \mathrm{m}$ $\mathrm{w}$ powietrzu $\mathrm{w}$ spawalni przed rozpoczęciem spawania, podczas spawania (tabl. I - szare słupki wskazują czas 5 kolejnych operacji spawania) i po zakończeniu spawania (pomiary AERO-TRAK)

Fig. 3. Surface concentration of particles from the range $0,01 \div 1 \mu \mathrm{m}$ in the air in the welding shop before, during (table I - grey pillars indicated time of 5 following operations of welding) and after welding (measurements with AERO-TRAK)

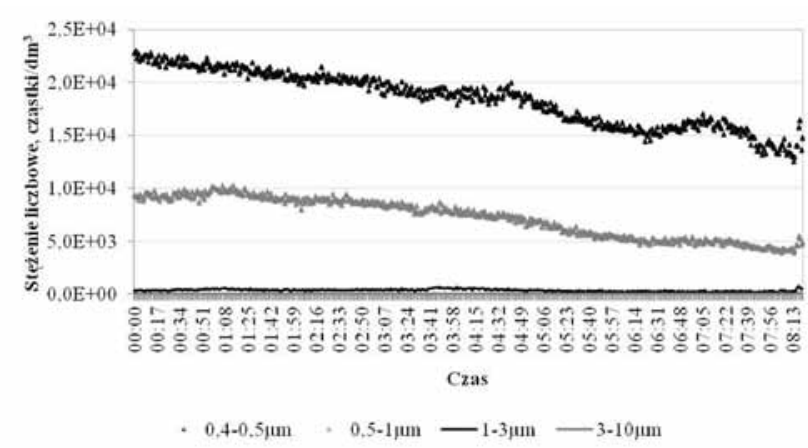

Rys. 4. Stężenie liczbowe cząstek $z$ zakresów: $0,4 \div 0,5 \mu \mathrm{m}$, $0,5 \div 1,1 \div 3$ i $3 \div 10 \mu \mathrm{m}$ w powietrzu w spawalni („to" w spawalni) przed rozpoczęciem spawania (pomiary GRIMM)

Fig. 4. Number concentration of particles from the range $0,4 \div 0,5$, $0,5 \div 1,1 \div 3$ and $3 \div 10 \mu \mathrm{m}$ in the welding shop ("background" in the welding shop) before welding (measurements with GRIMM) poprzedniego dnia na stężenia liczbowe cząstek, i mniejszy, niż w przypadku stężeń powierzchniowych (pomiary AERO-TRAK), wpływ prowadzenia rano prac przygotowawczych przed badania-

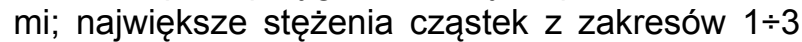
i $3 \div 10 \mu$ m wynosiły $0,07 \mathrm{e}^{4}$ cząstek $/ \mathrm{dm}^{3}$ (rys. 4 ),

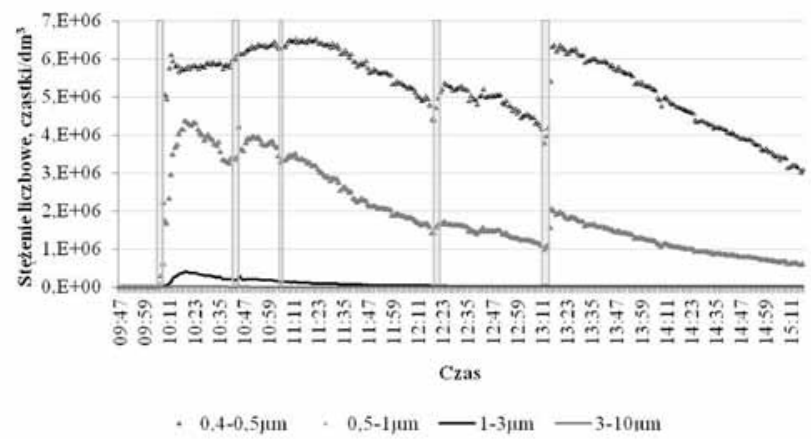

Rys. 5. Stężenie liczbowe cząstek z zakresów $0,4 \div 0,5 \mu \mathrm{m}, 0,5 \div 1$ $\mu \mathrm{m}, 1 \div 3 \mu \mathrm{m}$ i $3 \div 10 \mu \mathrm{m}$ w powietrzu w spawalni przed rozpoczęciem spawania, podczas spawania (tablica I - szare słupki wskazują czas 5 kolejnych operacji spawania) i po jego zakończeniu (pomiary GRIMM)

Fig. 5. Number concentration of particles from the range $0,4 \div 0,5 \mu \mathrm{m}$, $0,5 \div 1 \mu \mathrm{m}, 1 \div 3 \mu \mathrm{m}$ and $3 \div 10 \mu \mathrm{m}$ in the air in the welding shop before, during (see table I) and after welding (measurements with GRIMM)

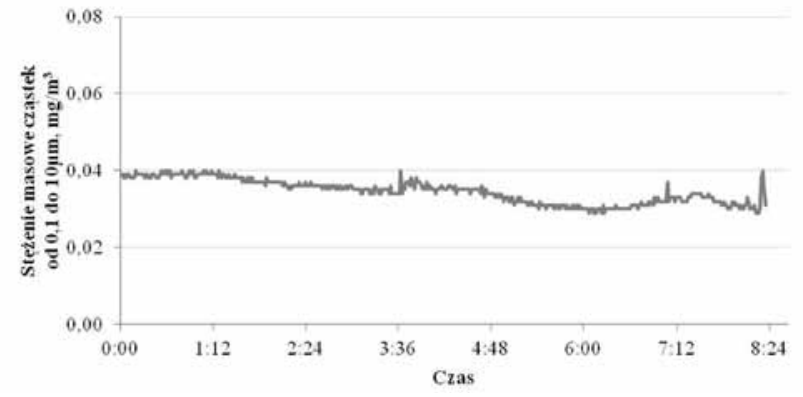

Rys. 6. Stężenie masowe cząstek z zakresu $0,1 \div 10 \mu \mathrm{m}$ w powietrzu w spawalni (,tto" w spawalni) przed rozpoczęciem spawania (pomiary DUST-TRAK)

Fig. 6. Mass concentration of particles from the range $0,1 \div 10 \mu \mathrm{m}$ in the air in the welding shop ("background" in the welding shop) before welding (measurements with DUST-TRAK)

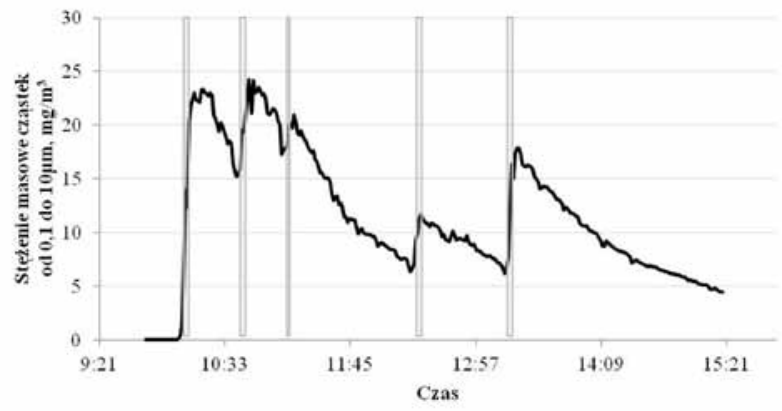

Rys. 7. Stężenie masowe cząstek z zakresu $0,1 \div 10 \mu \mathrm{m}$ w powietrzu w spawalni przed rozpoczęciem spawania, podczas spawania (tablica I - szare słupki wskazują czas 5 kolejnych operacji spawania) i po jego zakończeniu (pomiary DUST-TRAK)

Fig. 7. Mass concentration of particles from the range $0,1 \div 10 \mu \mathrm{m}$ in the air in the welding shop before, during (see table I) and after weIding (measurements with DUST-TRAK) 


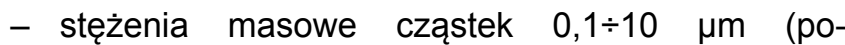
miary DUST-TRAK) zawierały się w zakresie 0,03 $\div 0,04 \mathrm{mg} / \mathrm{m}^{3}$, przy czym zmiany w wartościach stężeń nocą i ranem nie były tak widoczne, jak w przypadku pomiarów stężeń liczbowych wykonanych z użyciem miernika GRIMM.

Podczas całego dnia pracy spawacza i wykonywania prac spawalniczych omówionych w tablicy I, tzn. podCzas spawania stali elektrodami ER-150/F 6013, stężenia określone metodami zliczania dla cząstek z badanego zakresu $0,01 \div 10 \mu \mathrm{m}$ bardzo istotnie wzrosły.

Stężenia powierzchniowe cząstek o wymiarach $0,01 \div 1 \mu \mathrm{m}$ (rys. 3) osiągały maksymalne wartości do $11000 \mathrm{\mu m}^{2} / \mathrm{cm}^{3}$, podczas gdy przed spawaniem wynosiły $36 \div 55 \mu \mathrm{m}^{2} / \mathrm{cm}^{3}$ (rys. 2). A zatem, podczas spawania zaobserwowano nawet maksymalnie 306-krotny wzrost stężenia powierzchniowego cząstek, emitowanych jako cząstki ultradrobne i drobne (rys. 3). Po zakończeniu spawania jeszcze przez kilka godzin stężenia powierzchniowe cząstek zawieszonych w powietrzu były znacznie wyższe niż przed rozpoczęciem spawania.

Analizując dane przedstawione na rysunku 5 , można stwierdzić, że podczas spawania były emitowane, i utrzymywały się przez dłuższy czas w powietrzu, przede wszystkim cząstki o wymiarach z zakre-

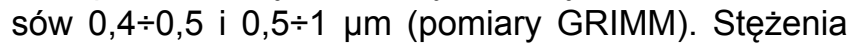
cząstek o wymiarach $0,4 \div 0,5 \mu \mathrm{m}$ były bardzo wysokie, wynosiły nawet $6,5 \mathrm{e}^{6}$ cząstek/dm ${ }^{3}$ i przekraczały zalecany zakres pomiarowy licznika. Stężenia cząstek o wymiarach $0,5 \div 1 \mu \mathrm{m}$ również były wysokie i wynosiły do $4,4 \mathrm{e}^{6}$ cząstek $/ \mathrm{dm}^{3}$. O ile w przypadku stężeń powierzchniowych cząstek (rys. 3) są wyraźnie zarysowane zmiany w zależności od momentu prowadzenia prac spawalniczych, to w przypadku wyników badań uzyskanych z zastosowaniem licznika GRIMM (rys. 5) zmiany te nie są tak widoczne, Cząstki z zakresów wymiarowych $0,4 \div 0,5$ i $0,5 \div 1 \mu \mathrm{m}$, które były emitowane do powietrza w spawalni, szczególnie w przypadku trzech pierwszych prac spawalniczych, utrzymały się w powietrzu niezależnie od przerw, które występowały pomiędzy wykonywaniem kolejnych prac spawalniczych. Podczas prowadzenia trzech pierwszych prac spawalniczych stwierdzono również wzrost stężeń cząstek z zakresu $1 \div 3 \mu \mathrm{m}$ maksymalnie do $3,6 \mathrm{e}^{5}$ cząstek/dm ${ }^{3}$.

Z rysunku 7 wynika, że podczas spawania stężenia masowe cząstek $0,1 \div 10 \mu \mathrm{m}$ określone za pomocą miernika DUST-TRAK osiągały maksymalne wartości do $25 \mathrm{mg} / \mathrm{m}^{3}$. Tak jak w przypadku danych uzyskanych z zastosowaniem miernika AERO-TRAK, są wyraźnie zarysowane zmiany w zależności od momentu prowadzenia prac spawalniczych. zaobserwowano, że jeżeli przerwy pomiędzy kolejnymi pracami spawalniczymi nie były zbyt długie, dochodziło do kumulowania się w powietrzu cząstek o wymiarach $0,1 \div 10 \mu \mathrm{m}$ pochodzących z wcześniejszych prac spawalniczych (np. podczas prowadzenia dwóch wcześniejszych prac). Po zakończeniu spawania jeszcze przez kilka godzin stężenia masowe cząstek o wymiarach $0,1 \div 10 \mu \mathrm{m}$ zawieszonych w powietrzu były znacznie wyższe od stężeń masowych określonych przed rozpoczęciem spawania w pomieszczeniu spawalni, które

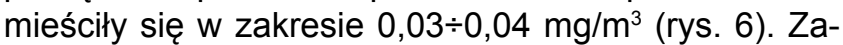
tem w wyniku spawania zaobserwowano maksymalnie 834-krotny wzrost stężenia masowego emitowanych cząstek o wymiarach $0,1 \div 10 \mu \mathrm{m}$

\section{Podsumowanie}

W wyniku analizy danych przedstawionych w artykule stwierdzono, że podczas całego dnia pracy spawacz może być narażony na zmienne ilości cząstek, $z$ reguły o wymiarach poniżej $10 \mu \mathrm{m}$, przy czym dymy spawalnicze zwykle zawierają większą liczbę cząstek ultradrobnych i drobnych, o wymiarach poniżej $1 \mu \mathrm{m}$. Podczas spawania stali elektrodami ER-150/F 6013:

- średnie udziały frakcji drobniejszych $\left(\mathrm{PM}_{0.25}, \mathrm{PM}_{0.5}\right.$, $\mathrm{PM}_{1}, \mathrm{PM}_{25}$ ) we frakcji PM10 wynosiły $64 \div 78 \%$, z czego $70 \%$ to cząstki o wymiarach poniżej $1 \mu \mathrm{m}$ (tabl. II),

- stężenia określone metodami zliczania dla cząstek z zakresu $0,01 \div 10 \mu \mathrm{m}$ bardzo istotnie wzrosły.

Maksymalnie wzrosły:

- 306-krotnie stężenia powierzchniowe cząstek o wymiarach $0,01 \div 1 \mu \mathrm{m}$ (rys. 3) określone za pomocą miernika AERO-TRAK,
- 500-krotnie stężenia liczbowe cząstek o wymiarach $0,4 \div 0,5 \mu \mathrm{m}, 1100$-krotnie stężenia liczbowe cząstek o wymiarach $0,5 \div 1 \mu \mathrm{m}$ i 515 -krotnie stężenia liczbowe cząstek o wymiarach $1 \div 3 \mu \mathrm{m}$ określone za pomocą licznika GRIMM (rys. 5),

- 834-krotnie stężenia masowe cząstek o wymiarach $0,1 \div 10 \mu \mathrm{m}$ określone $z$ użyciem miernika DUST-TRAK (rys. 7).

Uwzględniając te wyniki, należy przyjąć - tak jak w przypadku badań przeprowadzonych przy spawaniu stali kwasowej elektrodami OK 61.30/308L-17 [9] - że ocena narażenia na cząstki emitowane podczas spawania powinna być prowadzona w sposób kompleksowy i obejmować zarówno analizę stężeń masowych określanych metodą filtracyjno-wagową, jak i analizę rozkładów wymiarowych cząstek oraz ich stężeń liczbowych i powierzchniowych. 
Należy podkreślić, że podstawą metodyki stosowanej do oznaczania rozkładów wymiarowych, stężeń liczbowych oraz stężeń powierzchniowych cząstek $z$ reguły nie są pomiary w odniesieniu do średnicy aerodynamicznej cząstek, która jest najbardziej istotna z uwagi na ocenę procesu osadzania się cząstek w układzie oddechowym człowieka, niemniej jednak uzyskiwane wyniki dostarczają bardzo istotnych informacji dotyczących charakterystyki cząstek w momencie ich rzeczywistej emisji oraz zmienności tej emisji w czasie, obrazując rzeczywiste narażenie pracownika na cząstki zawarte w dymach spawalniczych.

\section{Literatura}

[1] PN-EN ISO 10882-1:2004 Zdrowie i bezpieczeństwo przy spawaniu i procesach pokrewnych. Pobieranie próbek cząstek zawieszonych w powietrzu i gazach w strefie oddychania spawacza. Część 1: Pobieranie próbek cząstek zawieszonych w powietrzu.

[2] PN-EN ISO 10882-2:2005 Zdrowie i bezpieczeństwo przy spawaniu i procesach pokrewnych. Pobieranie próbek cząstek zawieszonych w powietrzu i gazach w strefie oddychania spawacza. Część 2: Pobieranie próbek gazów.

[3] PN-Z-04008-7:2002+Az1:2004 Ochrona czystości powietrza. Pobieranie próbek. Zasady pobierania próbek powietrza w środowisku pracy i interpretacji wyników.

[4] PN-91/Z-04030/05 Ochrona czystości powietrza. Badania zawartości pyłu. Oznaczanie pyłu całkowitego na stanowiskach pracy metodą filtracyjno-wagową.

[5] PN-91/Z-04030/06 Ochrona czystości powietrza. Badania zawartości pyłu. Oznaczanie pyłu respirabilnego na stanowiskach pracy metodą filtracyjno-wagową.

[6] Rozporządzenie Ministra Pracy i Polityki Społecznej z dnia 29 listopada 2002 r. w sprawie najwyższych dopuszczalnych stężeń i natężeń czynników szkodliwych dla zdrowia w środowisku pracy (DzU nr 217, poz. 1833) wraz ze zm.
[7] Matczak W., Gromiec J.: Zasady oceny narażenia spawaczy na dymy i gazy. Instytut Medycyny Pracy im. prof. J. Nofera. Łódź 2003.

[8] Jankowska E. i in.: Badanie stężeń i rozkładu wymiarowego cząstek pyłów emitowanych w procesach wysokotemperaturowych. Projekt badawczy nr 2.R.03 zrealizowany w ramach programu wieloletniego pn. „Poprawa bezpieczeństwa i warunków pracy" etap I. CIOP-PIB, Warszawa, 2008-2010 [praca niepublikowana].

[9] Jankowska E.: Badanie narażenia spawaczy na cząstki zawarte $w$ dymach spawalniczych. Bezpieczeństwo Pracy, Nr 9 (480), 7-9, 2011.

Publikacja opracowana na podstawie wyników I etapu programu wieloletniego pn. „Poprawa bezpieczeństwa i warunków pracy”, sfinansowanego w latach 2008-2010 w zakresie badań naukowych i prac rozwojowych ze środków Ministerstwa Nauki i Szkolnictwa Wyższego/Narodowego Centrum Badań i Rozwoju. Koordynator programu: Centralny Instytut Ochrony Pracy - Państwowy Instytut Badawczy.

\section{Sekcja Spawalnicza}

\section{Stowarzyszenie Inżynierów i Techników Mechaników Polskich Oddział Warszawski zaprasza wszystkich członków SIMP i NOT na organizowane przez Sekcję Spawalniczą OW SIMP:}

\section{ODCZYTY TECHNICZNE}

\begin{tabular}{|l|l|l|}
\hline \multicolumn{1}{|c|}{ Terminy } & \multicolumn{1}{|c|}{ Prelegent, temat odczytu } & \multicolumn{1}{c|}{ Zakres tematyczny } \\
\hline $\begin{array}{l}\text { 22.03.2012 } \\
\text { godz. } 17^{00}\end{array}$ & $\begin{array}{l}\text { Mgr inż. ANDRZEJ RADZISZEWSKI } \\
\text { Badanie materiałów metalowych konstrukcji i ich złączy } \\
\text { metodą opartą na pamięci magnetycznej metalu }\end{array}$ & $\begin{array}{l}\text { Omówienie metody badania stanu makroskopowego } \\
\text { metalu w warunkach eksploatacji. Zebranie Zarządu. }\end{array}$ \\
\hline
\end{tabular}

Gmach Starny Technologiczny Wydziału Inżynierii Produkcji Politechniki Warszawskiej, ul. Narbutta 85, sala nr ST145, dojazd tramwajami 10,17 i 33

WYCIECZKI TECHNICZNE

\begin{tabular}{|l|l|l|}
\hline \multicolumn{1}{|c|}{ Terminy } & \multicolumn{1}{|c|}{ Nazwa instytucji, adres } & \multicolumn{1}{c|}{ Zakres zwiedzania / działalności } \\
\hline $\begin{array}{l}\text { 15.03.2012 } \\
\text { godz. 1100 }\end{array}$ & $\begin{array}{l}\text { Maroma Com Sp. z o.o. } \\
\text { ul. Wiejska 2C } \\
\text { Otrębusy }\end{array}$ & $\begin{array}{l}\text { Producent spawanych elementów mechanicznych ze stali wysokostopowych } \\
\text { i stopów aluminium dla elektroniki. }\end{array}$ \\
\hline
\end{tabular}

